\title{
GENDERING CITIZENSHIP: FAMILY CHANGE, POLITICAL CULTURE AND GENDER EQUALITY POLICIES IN SPAIN
}

\author{
KERMAN CALVO BOROBIA \\ Universidad de Salamanca
}

Recibido: 24/03/2014

Aceptado: 12/05/2014

\section{Resumen}

El artículo sostiene que las familias españolas han cambiado poco porque muchas mujeres no son verdaderamente ciudadanas. El análisis se basa en un examen de la igualdad de la formulación de políticas de género, para analizar las intersecciones entre las estrategias familiares, el empoderamiento de las mujeres y el cambio familiar. Se adopta un acercamiento amplio al concepto de ciudadanía, para observar no sólo el conjunto de los derechos legales normalmente asociados al concepto, sino también el inventario de las prácticas sociales y rituales que permiten a las personas disfrutar de la plena incorporación en la comunidad política, así como dotarlas de control total sobre su vida personal e íntima. La vida familiar y su organización, la ciudadanía y la igualdad de la formulación de políticas de género se entrecruzan de maneras múltiples y fundamentales: las políticas mal concebidas, y/o mal implementadas podrían dislocar a las mujeres, alejándolas de la ciudadanía plena; estos problemas, a su vez, pueden contribuir en gran medida a la consolidación de arreglos familiares tradicionales.

Palabras clave: Igualdad de género, cambios familiar, ciudadanía.

\begin{abstract}
This article argues that spanish families have changed little because many women are less than full citizens. The analysis draws on an examination of gender equality policy-making, to discuss the often-neglected intersections between family strategies, women's empowerment and family change. Citizenship is seen in an expansive way, to note not just the set of legal entitlements normally attached to the concept, but also the stock of social practices and rituals that allow individuals to enjoy full incorporation
\end{abstract}


in their policies as well as full control of their personal and even intimate lives. Family life and organization, citizenship, and gender equality policy-making intersect in manifold and fundamental ways: badly conceived, and/or badly implemented policies could dislocate women to push them away from full citizenship; these, in turn, can contribute greatly to the consolidation of traditional family arrangements.

Keywords: Gender equality, family change, citizenship. 


\section{Introduction}

Demographic and sociological analyses on the Spanish family have often insisted on a number of reasons why family decisions in Spain are somehow idiosyncratic. While most industrialized countries have virtually completed their so-called 'second demographic transition', that is to say, while family strategies have neatly departed from the traditional nuclear family model, a great number of Spaniards still prefer stable and institutionalized personal arrangements, with little geographical mobility. Very low fertility rates - a well-known characteristic of Spanish demographic behavior - are not to be taken as representing the arrival of new ideas on motherhood; they are, instead, a consequence of dominant institutional arrangements that force Spanish women to have fewer children than they would love to. In other societies family strategies reconcile stability, procreation but also individual preferences for autonomy, freedom or self-expression. In Spain, however, family life to a large extent is still embedded in traditional values as regards family forms, organization of domestic work or parent-son relations. The literature has of course noted the increasing popularity in Spain of alternative family arrangements ${ }^{1}$; these include de facto co-habitation, 'living apart together' arrangements, single parenthood and lesbian and gay family life ${ }^{2}$. Sharp decrease in fertility rates or the postponement of important decisions, such as marriage, are also the basis of much debate among Spanish sociologists, demographers and social anthropologists. Yet, in comparative terms, the Spanish family has changed relatively little. Most comparative analysis, not surprisingly, refer to

1. See, for instance, Moreno, Luis, and Pau MARí-KLOSE. «Youth, Family Change and Welfare Arrangements». European Societies 15.4 (2013), pp. 493-513.

2. DomingueZ-Folgueras, Marta, and Teresa CASTRO. «Cohabitation in Spain: No longer a marginal path to family formation». Journal of Marriage and Family 75.2 (2013), pp. 422-37; AYUSO, L. «Living apart together en España. ¿Noviazgos o parejas independientes?» Revista Internacional de Sociología 70 (2012), pp. 123-145; PICHARDO, José Ignacio. «We are family (or not): Social and legal recognition of same-sex relationships and lesbian and gay families in Spain» Sexualities 14.5 (2011), pp. 544-61. 
Spain as an example of an 'incomplete' 'second demographic transition', and also as a country insisting on 'familism's.

State policies have raised the costs of innovative decisions regarding the family in Spain. For instance, de facto couples face a fragmented regulation that paves the way for legal uncertainty; the lack of fiscal benefits is a drawback for couples preferring a less formalized arrangement. Surrogacy pregnancies as well as international adoptions face, also, increasing legal difficulties. Perhaps more importantly, the lack of generous social policies is constraining individual decisions as regards pregnancy, emancipation or single parenthood. Weakness in social spending for families, together with feeble State intervention in other areas of family policy (such as joint parental leave or public access to care for children aged 0 to 3 ) have prevented many women, and men, to combine work, personal and family life in ways that could have been more satisfactory for them ${ }^{4}$. As a consequence, many women seem bounded to fulfill care duties that reify old stereotypes about gender (different) roles and 'good' family practices 5 .

Cultural traditions also explain the persistence of 'familism'; in spite of the transformation of societal views towards new forms of family life, lots of people adhere still to traditional family practices that they see as morally right and socially respectable ${ }^{6}$. In other cases, patterns of socialization have also defined idiosyncratic expectations with regards to the family; Gaviria's comparison of young peoples' decisions in Spain and France showed how differently parent-children relations can be socially constructed in both countries $^{7}$. In Spain, access to adulthood is not assimilated with leaving one's family home; but it is so in France. Similarly, inter-generational obligations are defined in Spain in a very expansive way, to survive well beyond the age of personal emancipation ${ }^{8}$. The prolonged economic crisis is particularly affect-

3. SARASA, Sebastian. «Long-term care: the persistence of familialism». The Spanish Welfare State in European Context. Eds. Margarita León and Ana Marta Guillén. Ashgate, 2011, pp. 237-258.

4. For an overview of this argument, see MORENO, Almudena. «La protección familiar en España: un reto aplazado». Presupuesto y Gasto Público 71.2 (2013), pp. 223-40.

5. Moreno, Luis and MARÍ-KLose, Op. cit. 2013; LEÓN, Margarita. «Ideas, políticas y realidad: análisis crítico de la ley de dependencia. Papeles de Economía Española. 129 (2011): 2-14.

6. Cea D’Ancona, M. ${ }^{a}$ Ángeles. La deriva del cambio familiar: hacia formas de convivencia más abiertas y democráticas. Madrid: CIS, 2007.

7. GAVIRIA, Sandra. Juventud y familia en Francia y en España. Madrid: CIS, 2005.

8. For a critical revision of this argument based on recent data, see CAïs, J, and L FOLGUERA. «Redefining the dynamics of intergenerational family solidarity in Spain». European Societies 15.4 (2013), pp. 557-76. 
ing young people's personal and employment trajectories, shrinking the chances of an early personal emancipation?.

What policies, cultural traditions, as well as many other relevant factors have in common is that they shape family life by organizing women's lives. Women are at the heart of sociology's argument about family change (or lack thereof): when women's personal, political and economic status improves, in the sense of greater freedoms, autonomy and protection from violence, families change ${ }^{10}$. When women are entrapped in patriarchal social, cultural, economic and political relations, families are unlikely to change much. Contemporary process of individualization and instability of family arrangements are unavoidably connected with women that are less bounded to comply with expectations designed by actors external to them. Empowered women regain control over expanding dimensions of their lives, forcing birth and marital decisions to find new ways to accommodate to their equally important roles as professionals, consumers and/or decision makers.

I argue in this article that spanish families have changed little because many women are less than full citizens. And this remains so because even the most decisive effort to lift barriers to full citizenship for women - namely PSOE's gender equality policies between 2004 and 2011, has failed in important ways. Citizenship is thought here in an expansive way, to note not just the set of legal entitlements normally attached to the concept, but also the stock of social practices and rituals that allow individuals to enjoy full incorporation in their policies as well as full control of their personal and even intimate lives ${ }^{11}$. A higher likelihood of becoming the victim of personal violence affects one's status as citizen. Permanent absence from paid work also disrupts full citizenship. Family life and organization, citizenship, and gender equality policy making intersect in manifold and fundamental ways: badly conceived, and/or badly implemented policies could dislocate women to push them away from full citizenship; these, in turn, can contribute greatly to the consolidation of traditional family arrangements.

9. Recent comparative data on the number of young persons living at their parent's home can be found in EUROFOUND. Social situation of young people in Europe. Luxembourg: Publications Office of the European Union, 2014.

10. BECK-GERNSHEIM, Elisabeth. Reinventing the family: in search of new lifestyles. London: Polity, 2002.

11. PlumMer, Ken. Intimate citizenship: private decisions and public dialogues. Washington: University of Washington Press, 2003; GLUCKSMAnN, Miriam. «Developing an economic sociology of care and rights». Rights: Sociological Perspectives. Ed. L. Morris., 2006. 55-72.

Feminismo/s 23, junio 2014, pp. 69-89 
This article discusses policy making for women in Spain from 2004 to 2011. Gender equality was one of Rodríguez Zapatero's chief policy priorities during his terms in government. Rodriguez Zapatero sought to promote equality between women and men in all walks of life, including access to employment, work conditions, distribution of domestic work and access to power. During his first term (2004-2008) a wealth of new laws, together with the creation of new administrative units and the appointment of female politicians to key roles helped observers conclude that women's rights was possibly the area where Zapatero's promises had been better translated into policy initiatives $^{12}$. Zapatero's record during his second term (2008-2011) was less spectacular, yet still significant. As recently noted by Celia Valiente, in the second term, «there was less room for legislative reforms to improve women's status precisely because major legal changes had already passed between 2004 and 2008» ${ }^{13}$. Still, the Government upgraded women's issues to reach a Cabinet level position, and worked to deploy the policies introduced in the preceding years. Women's sexual and reproductive rights were also addressed, in an attempt to embed both pregnancy termination but also assisted reproduction into the new framework of citizenship and human rights.

Laws were passed and new discourses were pulled together. However, implementation has been weak and large domains of policy making of substantive interest for women remained untouched; this has resulted in women who remain largely indifferent to these policies, and who are hardly inclined to change social and political practices as a result of them.

\section{Gender equality policies in Spain}

Analyses on gender equality policies in Spain commonly differentiate between four broad phases. What defined Francoist policy making on women and the family (phase 1) was the institutionalization of the principle of male superiority. Notwithstanding some late legal reforms on civil and employment legislation, most policies justified gender inequality in the pursuit of family life and social cohesion. Democratic politics, particularly after 1982 (phase 2 ), slowly addressed this problem by, on the one hand, promoting equality

12. Pettit, P. Examen a Zapatero. Madrid: Temas de Hoy, 2008; See also Calvo, Kerman, «Calidad de la democracia, derechos civiles y reforma de la política». In La España de Zapatero: años de cambio, 2004-200. Eds. A. Bosco and I. Sánchez-Cuenca. Madrid: Fundación Pablo Iglesias, 2009. 205-227.

13. VALIENTE, Celia. «Gender equality policymaking in Spain (2008-11): losing momentum». Politics and society in contemporary Spain: from Zapatero to Rajoy. Eds. B. Field and A. Botti. Palgrave McMillan, 2013. 179-196. 
bodies at different levels and, also, by launching several nation-wide policy frameworks on equality. Existing work on the orientation and implementation of these frameworks highlight their limited achievements while, at the same time, pointing at significant differences at the sub-national level ${ }^{14}$. The notorious development of gender equality policies in Spain began in 2004 (phase 3): Rodriguez Zapatero focused on citizenship as a cornerstone for new politics, which addressed not only women, but also sexual minorities, democratic practices and immigration ${ }^{15}$. After 2011, with a new conservative government, and in a context of several spending cuts and ideological assaults on social-democratic ideas on welfare, culture and values, equality policies have simply banished from the public scene (phase 4).

During the Zapatero government (2004-2011), the parliament enacted a wealth of policies that touched on the rights and welfare entitlements of women. What sets Zapatero's policies apart is the fact that these were mostly rights policies: they activated the citizenship status of women to a degree, resonance and political saliency never achieved before. The literature on gender and politics in Spain provide some explanations for the incorporation of women's rights as a central element of the PSOE's ideological discourse ${ }^{16}$. In line with explanations about ideological change in the area of gay and lesbian rights, the electoral needs of the PSOE party (particularly after 1996) have been signaled as a reason for the decision of PSOE's leadership change of approach in the field of gender rights and representation. Women's mobilization, both outside and inside PSOE, is also partially responsible for the setting of a new agenda on women's rights. Lastly, the European Union had pressurized the Spanish national government to develop legislation incorporating principles and protections already established in countries with a longer tradition on women's rights protection.

Violence, equality and reproductive rights were the areas where concerns about female citizenship gained a clearer momentum between 2004

14. Bustelo, M. and E. Lomnardo. Políticas de igualdad en España y en Europa. Madrid: Cátedra, 2007.

15. Calvo, Kerman. Op. Cit.

16. VALIENTE, Celia. «Spain at the vanguard in european gender equality policies». Gender politics in the expanding European Union: mobilization, inclusion, exclusion. Ed. S. Roth. New York: Berghahn, 2008. 101-117; Also from this author, VALIENTE, Celia. «Women in Parliament: the effectiveness of quotas». Women and legislative representation: electoral systems, political parties, and sex quotas. Ed. Manon Tremblay. New York.: Palgrave Macmillan., 2008. 123-133; AstelARRA, Judith. Veinte años de políticas de igualdad. Madrid: Cátedra, 2005.

Feminismo/s 23, junio 2014, pp. 69-89 
and $2011^{17}$. These were the policies that incited evaluators to see Spain as a «young pioneer in gender policies» ${ }^{18}$. Note, however, that this is a somewhat narrow configuration of the space for women's public policies. Women's lives in general, and women's family choices in particular, are also (and perhaps to a much greater extent) shaped by public policies that are not framed, sold or understood as gender policies. A case at point would be the so-called dependency law, passed in 2006, which introduced a new range of benefits for people entrusted with caring for the disabled or the elderly ${ }^{19}$. What the law envisaged was the definition of different types of dependent people who could have free either the access to care services, such as in-home help or remote assistance, or receive monetary transfers. This piece of legislation, which was never presented as a women's rights policy, effectively established some state responsibility for the provision of care that liberated many women from having to provide care to relatives on an unpaid basis. Moreover, the failure of this policy explains many women's troubled access to citizenship, in as much as unpaid care obligations interfere with personal, social and political emancipation.

\subsection{Violence}

The fight against violence against women has been a priority for the Spanish feminist movement in the last two decades. The new policy on gender violence, passed in 2004, framed violence as located at the epicenter of a complex web of social, economic and cultural exchanges of power between men and women. Because of this, the 2004 Violence against women law set out to bring about significant changes in the legal entitlements of women. In the first place, the law has strengthened security measures; in the second place, it has given women remedial entitlements in the areas of social policies and housing intended to help victims of violence set a new life course ${ }^{20}$. For instance, victims of violence are expected to be given priority in the competition for public

17. On violence: Law 1/2004, 'Medidas de Protección Integral Contra la Violencia de Género'. On equality: Law 3/2007, 'Igualdad Efectiva entre Hombres y Mujeres'. On abortion: Organic Law 2/2010, 'de Salud Sexual y Reproductiva y de la Interrupción Voluntaria del Embarazo'.

18. LOMBARDO, E. Spanish policy on gender equality: relevant current legislation and policies. Ed. European Parliament, 2009.

19. On dependency: Law 39/2006, 'Promoción de la Autonomía Personal y Atención a personas en situación de dependencia'.

20. Coll-Planas, G., García-Romeral, G., Mañas, C., Navarro-Varas, L. «Cuestiones sin resolver en la ley integral de medidas contra la violencia de género: las distinciones entre sexo y género, y entre violencia y agresión». Papers 87.0 (2008); OsBORnE, R. Apuntes Sobre La Violencia De Género. Barcelona.: Bellaterra, 2009. 
housing. The law also granted rights, such as the right to be informed about development in court proceedings, free legal aid or access to «comprehensive social assistance» («asistencia social integral», as defined in section 19). In the area of criminal law, it introduced new legal mechanisms to enhance the safety of threatened women, including more powerful and efficient restriction orders for perpetrators of violence.

The new law polemically restricted its scope to the problem of male violence toward women only. In the opinion of many, this is justified in as much as the law is not merely protecting women as the victims of personal damage; the law is protecting women to avoid social and structural damages linked with the solidification of long-lasting inequalities. On the contrary, radical feminist scholars and activists, gay and lesbian campaigners together with sociologists familiar with «queer» theoretical ideas have always abhorred this limitation in scope $e^{21}$. The Spanish Constitutional Tribunal agreed with those measures that augmented punishment when males were exerting violence against their partners.

A significant transformation in the organization of criminal justice also occurred as a consequence of this policy: 17 specialized courts were initially created which were solely concerned with gender violence and another 417 judicial sections were also primarily entrusted with dealing with these cases even if, in this case, judges may also hear cases of a different nature ${ }^{22}$. Additional provisions resulted in 6 further specialized courts in subsequent years. Initially, 50 prosecutors were assigned to these new courts, yet the number has grown in later years.

\subsection{Equality}

While the law on violence engages with basic civil rights, the equality law dealt with some important aspects of women's political and social citizenship $^{23}$. The law's chief aim was to promote gender equality in all walks of life, including working conditions and the representation of women in elected bodies (at all state levels) and in the governing bodies of large companies. High-ranked socialist politicians linked the upcoming 'ley de igualdad' with a transformation in citizenship practices and with an overhauling of traditional

21. See, for instance, Osborne, $\mathrm{R}$, «De la 'violencia' (de género) a las 'cifras de la violencia': una cuestión política». Empiria 15 (2008): 99-124.

22. CONSEJO GENERAL DEL PODER JUDICIAL. La Justicia dato a dato 2008.

23. LÓPEZ, J. «Los principios rectores de la LO 3/2007 sobre igualdad efectiva entre mujeres y hombres a la luz de las estrategias de "gender mainstreaming» y «empowerment»". Revista del Ministerio de Trabajo e Inmigración Extra 2, (2007), PP. 53-67. 
gender relations. The bearing of this legislation on family choices was also often stressed; in as much as new parental leave rights were introduced: in promoting joint care of recently born babies, sociologist Soledad Murillo, Secretary of State for equality between 2004 and 2008, saw this law as protection against discriminatory work practices that jeopardize the working careers of young mothers ${ }^{24}$.

According to these grand ambitions, the equality law worked at a threefold level. First, the law clarified the meaning of discrimination and harassment. This was meant to facilitate judicial redress ${ }^{25}$. In doing so the Spanish government adopted two European Union (EU) directives: Directive 2002/73/ $\mathrm{EC}$ on the implementation of the principle of equal treatment for men and women regarding access to employment, vocational training and promotion, and working conditions; and Directive 2004/113/EC implementing the principle of equal treatment between men and women in the access to and supply of goods and services. Second, the law had an affirmative action dimension in so far as new obligations were introduced for public bodies and institutions to develop equality plans and initiatives regarding the equal treatment of men and women. Third, and perhaps most importantly, the law introduced positive discrimination as a legitimate policy priority.

The equality policy also built on initiatives at the international and sub-national levels to introduce quotas for the representation of women. It established a route map for gender equality in the governing bodies of large companies: companies with more than 50 employees are requested to proceed with a ten per cent annual increase in the presence of women in those bodies. The target is that by 2015,40 per cent of these positions will be held by women. Note that the law does not include enforcement mechanisms or penalties if these targets are not met; companies are now simply expected to draft unbinding equality action plans. In the area of political representation, political parties are now required to assure that neither sex has a representation higher than 60 per cent or lower than 40 per cent of candidate positions on election lists. Regional electoral laws are also allowed to set a more equal gender balance when it comes to elections at that level. The equality law, however, gives political parties a great degree of freedom to decide on the placement of candidates on the list (provided that at least two women are included in every group of five candidates), and also on the selection of candidates for

24. <http://www.ugt.es/Mujer/crisalida/00052/Ley\%20Igualdad\%20comentada.html>, last accesed 12 may 2014.

25. PÉREZ Del Río, T. «La Ley Orgánica de Igualdad Efectiva entre Mujeres y Hombres. Aproximación para el debate». Revista de Derecho Social 37 (2007): 223-50. 
the top positions on the list. These characteristics explain much of the limited impact of quota policies in effectively causing gender equality at the level of political representation ${ }^{26}$.

\subsection{Presence and pregnancy termination}

Rodriguez Zapatero paid much attention to the question of female presence. In March 2004 the first appointed cabinet had, for the first time in Spanish recent democracy history, the same number of female and male ministers. Similarly significant was the appointment of women as deputy prime ministers in both of his terms in government. A number of equally resonant decisions followed in the years to come, including the appointment of female ministers for defense or the economy. It should be noted that with hardly two exceptions, all of his Cabinets had as many women as men. This policy, however, had a less obvious impact at lower levels of Government, where men have always been clearly overrepresented ${ }^{27}$. In promoting access of women to high-ranked office, Spanish policy makers endorsed the argument long ago presented by political philosophers, social scientists and activists alike that praised 'presence' for a twofold reason. In the first place, a higher proportion of women in power «sends a clear message to society that the government is seriously committed to giving political power to women ${ }^{28}$. In the second place, female power-holders often behave differently than their male peers. Rodriguez Zapatero possible thought this way when appointing Bibiana Aido as the first ever Minister of Equality, between 2008 and 2010.

Rodriguez Zapatero's second term in Government was very different from his first; a worsening economic scenario together with a less robust Parliamentary majority constrained the Government's room for maneuver. 'Soft' policy issues, such as equality, were sidelined to promote more traditional policies on 'hard' traditional issues (employment, security, identity). Gender equality lost momentum after 2008; more than that, it became a contentious political issue. Violence never had become a dividing issue among the large political parties. Equality stirred a low-voiced confrontation that ended in a

26. VERGE, T. «Institutionalizing Gender Equality in Spain: Incremental Steps from Party to Electoral Gender Quotas». West European Politics 35.2 (2012): 395-414; See also MARTíneZ, A., and Kerman CALVO. Un análisis del efecto de la ley de igualdad en la representación electoral, parlamentaria y en el comportamiento electoral de las mujeres en las elecciones generales de 2008. Madrid: Fundación Alternativas, 2010.

27. Detailed information can be found in < http://www.inmujer.gob.es/estadisticas/consulta.do?area $=8>$, last accessed May 13th 2014.

28. Valiente, C. Op. Cit., p.183.

Feminismo/s 23, junio 2014, pp. 69-89 
technical question before the Constitutional Court, in as much as the Popular Party resented the introduction of compulsory electoral quotas. In a somewhat uninspiring ruling, particularly for those who expected a firmer backing of positive discrimination as a policy principle, the Court accepted electoral quotas but not for the reasons produced by the Government: the law was accepted as constitutional because it established equality among the sexes, and not because it discriminated in favor of women ${ }^{29}$.

Conservative political and social organizations deeply opposed the reform of abortion legislation. During the second term, possibly the chief legal reform related to women's right was the introduction in 2010 of abortion on demand. To align with many western countries, the new law defined pregnancy termination as a basic human right of women (in this sense, the reform was included in legislation on sexual and reproductive rights of women); it allowed women to do so freely during the first 14 weeks of pregnancy. Minors under sixteen years of age were also granted this right, even in the absence of parental consent. In terms of practical application, the reform was not actually expanding women's repertoire of possibilities much: the way the previous legislation was applied had already allowed many women to have an abortion even in the absence of rape, fetal malformation or health risk. In symbolic terms, abortion on demand signaled an expansion of citizenship rights to a level that clashed with the interests and principles of the Catholic Church and other conservative groups.

\section{Policy making, citizenship and women's political behavior}

Citizenship is, or at least it should be, a fundamental agent for family change in ways that are more favorable to women. Public policies in the field of rights recognition are of course a very important element for acquiring full citizen$\operatorname{ship}^{30}$. Citizenship, however, needs to be assimilated, routinized and incorporated in daily social and political practices. But, are they so?

Public Opinion seems to have liked PSOE's gender equality policies. In 2008, as shown in table 1, and when public opinion on Rodriguez Zapatero ranked still at positive levels, gender equality was the policy domain where evaluations were more generous. Almost half of the men surveyed gave a

29. Business associations also opposed the sections of the equality law imposing quotas on business (PÉREZ DEL RIO, T. Op. Cit., p. 233). In this case they succeeded in their quest, as the government finally trimmed down the law eliminating the penalties in those cases where companies failed to meet their legal obligations.

30. HyNES, P., et al. «Sociology and human rights: confrontations, evasions and new engagements». Eds. P. Hynes, et al. London: Routledge, 2011. 2-14. 
positive evaluation to gender equality policies. Gender policies were also the most popular policies among women ${ }^{31}$. In spite of the eroding credibility of Rodriguez Zapatero as a Primer Minister after 2008, his policies in the area of women's rights remained popular. In November 2011, hardly 20 per cent of spaniards thought that Socialist policies in the field of gender were misguided $^{32}$. This strikes as a remarkably good result, considering the appealing social evaluations of policies in all other walks of life. It is safe to argue that the Spanish Socialists' Workers Party (PSOE) is seen as the most capable party to promote women's rights.

Table 1. Evaluation of government's policies by men and women (2004-2008)

\begin{tabular}{|l|c|c|c|c|c|}
\hline & Men & Women & Women-Men & & Total \\
\hline Equality men/women & $47 \%$ & $37 \%$ & $-10 \%$ & $*$ & $42 \%$ \\
\hline Rights & $36 \%$ & $30 \%$ & $-6 \%$ & $*$ & $33 \%$ \\
\hline Social issues & $37 \%$ & $31 \%$ & $-5 \%$ & $*$ & $34 \%$ \\
\hline Infrastructures & $39 \%$ & $34 \%$ & $-5 \%$ & $*$ & $36 \%$ \\
\hline Education & $29 \%$ & $24 \%$ & $-4 \%$ & $*$ & $26 \%$ \\
\hline Science and technology & $27 \%$ & $24 \%$ & $-4 \%$ & $*$ & $25 \%$ \\
\hline Security & $25 \%$ & $22 \%$ & $-4 \%$ & $*$ & $24 \%$ \\
\hline Territorial & $20 \%$ & $17 \%$ & $-4 \%$ & $*$ & $18 \%$ \\
\hline Health & $38 \%$ & $34 \%$ & $-3 \%$ & ns & $36 \%$ \\
\hline Environment & $34 \%$ & $31 \%$ & $-3 \%$ & ns & $33 \%$ \\
\hline Employment & $12 \%$ & $10 \%$ & $-3 \%$ & $*$ & $11 \%$ \\
\hline Housing & $9 \%$ & $7 \%$ & $-2 \%$ & ns & $8 \%$ \\
\hline Economy & $8 \%$ & $7 \%$ & $-1 \%$ & ns & $7 \%$ \\
\hline Immigration & $15 \%$ & $14 \%$ & $-1 \%$ & ns & $14 \%$ \\
\hline
\end{tabular}

* Cells are significant at $\mathrm{p}<0,05$.

Good policy evaluations, however, are a bad indicator of policy impact. Much to the contrary, there is strong indication that socialist gender equality policies are not conquering women's hearts in Spain. To begin with, Spanish women do not behave politically in any distinctive way. While women are, on the

31. Centro de Investigaciones Sociológicas (CIS) study number: 2775.

32. Centro de Investigaciones Sociológicas (CIS) study number: 2920.

Feminismo/s 23, junio 2014, pp. 69-89 
whole, somewhat more likely to vote for the PSOE than for the $\mathrm{PP}^{33}$, existing evidence confirms the disappearance of a gender gap in conventional political participation Worse, when differences exist, they define women as less politically informed and interested in politics than $\operatorname{men}^{34}$. Neither the general discourse on citizenship, not the specific battery of policies in women's rights designed and implemented in Spain from 2004 to 2011 have changed the political behavior of Spanish women in any dramatic or significant way. Some research on the topic has showed that only a very small group of women might have changed their vote directly as a reward to PSOE's feminist agenda; these would be leftist women, with a record of support for political parties such as Izquierda Unida (United Left, IU), who know about policy making in this field and, besides, are happy with how these policies are oriented ${ }^{35}$.

Similarities in voting and other forms of conventional participation between men and women move the focus onto citizen's evaluations of policies. Is it not the case that women are to like those policies that empower them? As also shown in the table, and contrary to all expectations, women are consistently less supportive of policies than men; this included equality policies, to the extent that this was where the gender gap was the widest. In general terms, it is ideology what drives policy evaluations, not gender: leftist women are supportive of these policies not because of their gender, but, instead, because of their political identity. As a matter fact, in Spain conservative women are the social group with more negative views towards gender equality policy making ${ }^{36}$. That only a few Spanish women see themselves as 'feminists' further reinforces this argument. In January 2014, for instance, less than 3 per cent of women chose feminism from the list of political labels that could define their political ideology. A meager extra 4 per cent went for

33. Martínez, A and K. Calvo. Op. Cit.

34. Verge, T, and Raül TORMOS. «La persistencia de las diferencias de género en el interés por la política». Revista Española de Investigaciones Sociológicas 138 (2012): 89-108. In a recent analysis, Alberto Penadés, and using data on declared voting future preferences (and not voting recall) argues that women were until recently more clearly on the side of the PSOE; this, he argues, made women at first more loyal to the PSOE. In other words, they were less inclined to vote for the PP despite the horrible economic scenario of Zapatero's final months in power. See PENADÉS, A. ¿A la caza del voto femenino? Ya podéis correr, 2014. Blog Piedras De Papel: http://www.eldiario.es/piedrasdepapel/ caza-voto-femenino-podeis-correr_6_232786721.html.

35. Martinez, A., K CalVo, and I. Martín. «Do good policies foster loyalty? Women, voting and ideology in Spain». VIII Congreso Vasco de Sociología y Ciencia Política. Bilbao. 2010.

36. CALVO, K. ¿Por qué son las mujeres españolas indiferentes a las políticas públicas por la igualdad? 2013. Blog Agenda Pública.

Feminismo/s 23, junio 2014, pp. 69-89 
feminism as a second option. This percentage has been remarkably consistent for more than a decade.

It appears that the expected connections between policy making and women's social and political practices are broken. In spite of heightened efforts, citizenship empowering policies might be failing. Spanish women are well aware of their disadvantaged position when it comes to fundamental personal choices, including those affecting family life. But this does not translate into new individual empowering practices or a firmer engagement with institutional politics. What would be the explanation for this? One explanation would pay attention to the problem of implementation. Gender equality policies are designed to incorporate women into social, cultural and economic social worlds in new, and hopefully better ways. In becoming full citizens, women could regain control over a wide range of personal decisions that are bounded to have consequences on changing configurations of family life (among other things). All this, however, might be of little consequence if policies are not properly deployed.

The policies discussed in this article constituted a rather ambitious package of citizenship-making political initiatives. Most of them, however, call for considerable effort in terms of budget and intergovernmental coordination as in Spain social service provision is the purview of regional and local governments. This might explain why gender equality policies have always suffered from weak and fragmented implementation in Spain ${ }^{37}$. To be more precise, three problems hamper the process of implementation. (1) In the first place, the policies that draw from the idea of gender mainstreaming clash with some of the most entrenched modes of functioning in Spanish bureaucracies (most of which rely on single-issue organizations with little horizontal co-operation). (2) In the second place, intergovernmental relations are often marred by political infighting between the two large national political parties. (3) Lastly, the current economic crisis has made the implementation of any measure a difficult task.

Focusing on the issue of violence for the sake of illustration, one should begin by noting that the current conservative government has cut down public funds for prevention and support in more than 20 per cent ${ }^{38}$. As a matter of fact, that implementation was to become a serious difficulty became apparent at an early hour. The Spanish chapter of Amnesty International soon claimed that 'the law has made a weak impact on the pathway of those women

37. Lombardo, E. Op. Cit.

38. <http://www.abc.es/20120413/espana/abci-observatorio-contra-violencia-genero201204122038.html. Last accessed 1 may 2014.

Feminismo/s 23, junio 2014, pp. 69-89 
surviving gender violence ${ }^{39}$. Several of the provisions of the law were simply inoperative, while lack of coordination soon resulted in gross differences across regions in terms of levels of protection ${ }^{40}$. The law has not been effective at reducing killings; the number of women killed by their male partner while they were protected with a restriction order increased from 20 per cent in 2005 to 30 percent in 2007. The trend has held. The same is true for those women actually filing criminal complaints against their abusers: the number of these women ultimately killed also rose between 2005 and 2008. The implementation of the equality law was also fraught with difficulties. Some of them were again related to the decentralized nature of the Spanish state: while rights-based policies remain the exclusive province of the central government, the obligatory participation of several levels of government in the definition of new welfare entitlements severely hinders the short-term effectiveness of this type of initiative.

Faulted implementation must be a key part of the explanation of why gender equality policies are causing little effect on women's personal and political identities and behavior. However, there is another element to consider. Family choices, as an example of the large array of persona decisions that depend on women's citizenship status, are sensible to how operational definitions of gender 'equality' are. Equality has become both a site for academic thinking but also a specific domain for policy making. Some issues are labeled as 'equality' by policy makers according to criterion that are not always shared or understood by common people. Women could insist on larger autonomy in family life if they felt that their rights are close to those of men, regardless of the label imposed to those policies procuring this leveling. In Spain, large policy domains of extraordinary relevance for women's lives remain largely unscathed. Equality policies might be tapping on issues perceived as important by scholars and elites, but not by common women facing non extraordinary, but very important daily decisions. The issue of women and paid work is of course a good illustration to highlight with citizenship needs to be engaged in very generous terms: equality practices and economic equality are as important and formal legal entitlements. Women's employment trajectories in Spain, for instance, have not changed at the required speed so that Spanish families can converge with societies more embedded in aforementioned 'second demographic transition'. And recent reforms of labor law have worsened

39. AMNISTÍA INTERNACIONAL. Obstinada realidad, derechos pendientes tres años de la Ley de Medidas de Protección Integral contra La Violencia de Género, 2008.

40. AMNISTÍA INTERNACIONAL Pongan todos los medios a su alcance, por favor. dos años de Ley Integral contra la Violencia de Género. 2007. 
this problem. The main conclusions of the large literature on women and work are: (1) women have a much more difficult access to paid work than men; (2) once in the work force, women are more likely to suffer from adjustments in the labor market, often resulting in higher unemployment rates; (3) women are much more likely to work part time or in unstable contracts; (4) but women, if working full time, are likely to face working days as long as those of men; (5) this results in choices that are gender specific: women (but not men) must decide whether to have children or work at all. Little of bad access to employment works to reinforce old ('functionalist') views on gender roles. Failed by a segmented work market and a plethora of invisible entry barriers, many women have been reinstated in their role of carers. This gives a lot of fuel to traditional family practices that rest on clear and distinctive family roles for men and women.

The gender distribution of domestic work is a similar area of fundamental relevance for a solid linkage between citizenship and family change to be consolidated. Very little has been attempted, and achieved, in Spain to make men to engage with unpaid domestic work. It is true that the last Socialist cabinet approved legislation on domestic workers by Royal Decree $e^{41}$ that significantly improved the working conditions of those (most women) working as such in the formal economy. In Spain around 15\% of households hire some sort of domestic service. However, this is of no significance for the actual distribution of domestic work in most families; the literature on the subject as regards the Spanish case agrees on noticing a biased distribution that has women providing a much greater share of unpaid domestic work. According to some research, nearly half of Spanish women do all domestic chores without any help ${ }^{42}$. In spite of changing attitudes as regards how family life should be, the reality of Spanish households is still one where most men are free of the most unappealing domestic duties. This, as noted above, includes not only cleaning and household organizations, but more dauntingly caring activities and full responsibility for dependent people.

\section{Conclusions}

Sexual citizenship should be at the heart of any discussion of family life and family formations in Spain. Survey data shows that Spanish women are not exactly living the kind of family life they would like to: they marry later, have less children, divorce less or face a larger share of 'private' family duties

41. Royal Decree 1620/2011, of November 14.

42. Verge, T and Tormos, R. Op. Cit. p.95.

Feminismo/s 23, junio 2014, pp. 69-89 
precisely because access to paid work is so difficult for many. More than that, in many cases their freedom to react to shifting life conditions is also curtailed by different forms of institutionalized and non-institutionalized violence, being physical violence only but the most visible expression of a much larger problem. Most feminist thinkers, but also a larger number of policy makers are converging into thinking that citizenship is to be called for these problems to be rightfully addressed. Leaving aside formalistic understanding of the concept, a more aggressive assault on real citizenship for women should be promoted so that both men and women can fulfill their often distinctive personal aspirations.

Between 2004 and 2011, successive socialist governments thought that such an assault was on the making. New policies were launched that embodied most of the more established principles and claims of the women's movement. Violence, equality, access to power or pregnancy termination became policy goals in the hands of new bureaucracies and high-ranked public officials. Jose Luis Rodríguez Zapatero famously defined himself as a 'feminist', making constant public displays of his commitment to a balanced gender representation in all walks of life. These policies, however, might not be working. Many Spanish women are still forced to make difficult decisions when it comes to reconcile family and professional life. Many women are less than full citizens. In spite of unquestionable symbolic victories in the fields of presence and representation, many women are hardly impressed by gender equality policy making, and refuse to develop particularistic identities that insist on their differences with men.

The problem surely is one that combines deficiencies in both supply and demand. On the supply side, equality policies appear to be badly implemented; they also fail to tackle fundamental problems. On the demand side, women seem impervious to political initiatives that appeal to their particularistic experiences, practices and problems as women. Unfortunately, it is unlikely that progress will be made in this area in the near future: the current conservative government is openly challenging the basic elements of the previous framework for women's citizenship. Appealing to a difficult economic scenario, conservative politicians are questioning the need for State intervention in a wide array of social issues, including women's rights. It is perhaps urgent for women's groups, and also for observers and students of women's issues, to recuperate the debate on what are the differences between entitlements, privileges and rights, if a fully-fledged access to citizenship is to be effectively granted for all women. 


\section{References}

AMNISTÍA INTERNACIONAL. Obstinada realidad, derechos pendientes tres años de la ley de medidas de protección integral contra la violencia de género. 2008.

- Pongan todos los medios a su alcance, por favor. Dos años de ley integral contra la violencia de género. 2007.

Astellarra, Judith. Veinte años de políticas de igualdad. Madrid: Cátedra, 2005.

AYUSO, Luis. Living apart together en España. ¿Noviazgos o parejas independientes? Revista Internacional de Sociología. (2012) 70: 123-157.

BECK-GERNSHEIM, Elisabeth. Reinventing the family: In search of new lifestyles, London: Polity, 2002.

Bustelo, María y Lombardo, Emanuela. Políticas de igualdad en España y en Europa. Madrid: Cátedra, 2007.

CALVO, Kerman. ¿Por qué son las mujeres españolas indiferentes a las políticas públicas por la igualdad? Blog Agenda Pública: Eldiario.es, 2013.

- «Calidad de la democracia, derechos civiles y reforma de la política» en $\mathrm{La}$ España De Zapatero: Años De Cambio, 2004-200, eds. A Bosco, I SánchezCuenca, 205-27. Madrid: Fundación Pablo Iglesias, 2009.

CAÏs, Jordi y FOLGUERA, Laia. Redefining the dynamics of intergenerational family solidarity in Spain. European Societies. 15: 557-76, 2013.

Cen D’Ancona, María Áangeles. La deriva del cambio familiar: Hacia formas de convivencia más abiertas y democráticas, Madrid: CIS, 2007.

Coll-Planas, Gerard; García-Romeral Moreno, Gloria; Mañas RodríGuez, Carmen y NARARRO-VARAS, Lara. Cuestiones sin resolver en la ley integral de medidas contra la violencia de género: Las distinciones entre sexo y género, y entre violencia y agresión. Papers. Revista de Sociología. 87, 2008.

CONSEJO GENERAL DEL PODER JUDICIAL. La justicia dato a dato 2008, 2008. Dominguez-Folgueras Marta y CAStro-Martín Teresa. Cohabitation in Spain: No longer a marginal path to family formation. Journal of Marriage and Family. 75: 422-37, 2013.

EUROFOUND. Social situation of young people in Europe. Publications Office of the European Union, Luxembourg, 2014

GAVIRIA, Sandra. Juventud y familia en Francia y en España, Madrid: CIS, 2005.

GLUCKSMANN, Miriam. «Developing an economic sociology of care and rights» en Rights: Sociological Perspectives, ed. L Morris, 55-72, 2006.

Hynes, Patricia; LAMB, Michele; SHORT, Damien y WAITES, Matthew. «Sociology and human rights: Confrontations, evasions and new engagements» en Sociology and Human Rights: New Engagements, eds. P Hynes, M Lamb, D Short, M Waites, 2-14. London: Routledge, 2011.

LEÓN, Margarita. Ideas, políticas y realidad: Análisis crítico de la ley de dependencia. Papeles de Economía Española. 129: 2-14, 2011. 
LOMBARDO, Emanuela. Spanish policy on gender equality: Relevant current legislation and policies, 2009.

LÓPEZ, Julia. Los principios rectores de la LO 3/2007 sobre igualdad efectiva entre mujeres y hombres a la luz de las estrategias de "gender mainstreaming» $y$ "empowerment»'. Revista del Ministerio de Trabajo e Inmigración. Extra 2: 53-67, 2007.

Martínez, Álvaro y CALvo, Kerman. Un análisis del efecto de la ley de igualdad en la representación electoral, parlamentaria y en el comportamiento electoral de las mujeres en las elecciones generales de 2008. Madrid: Fundación Alternativas, 2010.

Martínez, Álvaro; CALVo, Kerman y Martín, I. Do good policies foster loyalty? women, voting and ideology in Spain. Presented at VIII Congreso Vasco De Sociología y Ciencia Política. Bilbao, 2010.

Moreno, Almudena. La protección familiar en España: Un reto aplazado. Presupuesto y Gasto Público. 71: 223-40, 2013.

Moreno, Luis y MARÍ-KLOSE, Pau. Youth, family change and welfare arrangements. European Societies. 15: 493-513, 2013.

Osborne, Raquel. Apuntes sobre la violencia de género. Barcelona: Bellaterra, 2009. De la 'violencia' (de género) a las 'cifras de la violencia': Una cuestión política. Empiria. 15: 99-124, 2008.

PENADÉS, Alberto. ¿A la caza del voto femenino? ya podéis correr. Blog Agenda Pública: Eldiario.es, 2014.

PÉREZ DEL Río, María Teresa. La ley orgánica de igualdad efectiva entre mujeres y hombres. Aproximación para el debate. Revista de Derecho Social. 37: 223-50, 2007.

PetTit, Philip. Examen a Zapatero. Madrid: Temas de Hoy, 2008.

PICHARDO, José Ignacio. We are family (or not): Social and legal recognition of samesex relationships and lesbian and gay families in Spain. Sexualities. 14: 544-61, 2011.

Plummer, Kenneth. Intimate citizenship: Private decisions and public dialogues, Washington: University of Washington Press, 2003.

SARASA, Sebastián. «Long-term care: the persistence of familialism» en The Spanish Welfare State in European Context, eds. M León, AM Guillén, 237-58. Ashgate, 2011.

VAliEnte, Celia. «Gender equality policymaking in Spain (2008-11): Losing momentum» en Politics and Society in Contemporary Spain: From Zapatero to Rajoy, eds. B Field, A Botti, 179-96. Palgrave McMillan, 2013.

- «Spain at the vanguard in European gender equality policies» en Gender Politics in the Expanding European Union: Mobilization, Inclusion, Exclusion, ed. S Roth, 101-17. New York: Berghahn, 2008. 
— «Women in parliament: The effectiveness of quotas» en Women and Legislative Representation: Electoral Systems, Political Parties, and Sex Quotas, ed. M Tremblay, 123-33. New York: Palgrave Macmillan, 2008.

VERGE, Tània. Institutionalising gender equality in Spain: Incremental steps from party to electoral gender quotas». West European Politics. 35: 395-414, 2012.

VERGE, Tània, TORMÓN, Raul. La persistencia de las diferencias de género en el interés por la política. Revista Española de Investigaciones Sociológicas. 138: 89-108, 2012. 